\title{
Students' Perceptions and Attitudes of Self -Efficacy Oriented by Research- Inquiry
}

\author{
Cansu EBREN OZAN \\ Amasya University Science Institute, Amasya, Turkey
}

Özgen KORKMAZ

Amasya University Technology Faculty Department of Computer Engineering, Amasya, Turkey

\section{Article history}

Received:

02.04.2018

Received in revised form: 25.05.2018

Accepted:

28.05.2018

Key words:

Inquiry-based learning,

Attitude, Science culture

\begin{abstract}
The purpose of this research is to determine whether there is a meaningful relationship between secondary school students' attitude and perception levels of self-efficacy oriented by research-inquiry and as well whether students' attitude and selfefficacy levels differ according to grade and gender. The working group of the study consist of 234 secondary school students. The descriptive model of one of the quantitative research methods was used in this research. The data of the study was collected with Perception Scale of Self-Efficacy Oriented by ResearchInquiry and Attitude Scale Oriented by Research-Inquiry. Percentages, mean, Anova, Schieffe and $t$ tests have been benefited in this study. According to data obtained from the study, it has been concluded that students' attitude and selfefficacy levels oriented by research-inquiry were in a high level, it hasn't differed according to gender, there was a significant difference against the 8th Grade students between Grade 8 and Grade 5 and 7 regarding to the attitude level, there was a significant difference against the 8th Grade students between Grade 8 and Grade 6 and 7 regarding to self efficacy level, there was a positive and meaningful relationship between the levels of attitude and self - efficacy at a high level.
\end{abstract}

\section{Introduction}

In today's world, where science and technology are becoming increasingly important, it can be said that the main objective of our education system is that students structure the information rather than receive ready information and are raised as scientific literates (Bozdoğan, 2016). Qualified people who produce, reach and use the information are required for this (Ün Açıkgöz, 2011). Undoubtedly, there are many variables in achieving this objective. It is possible to say that science teaching is among them. Thus, it is also emphasised that science teaching programs and science lessons are also quite important in this sense (Arslan, 2005).With science lessons, individuals get the opportunity to have experiences regarding scientific processes and science, and adapt the information they obtain from these experiences into their lives in different situations (Yaşar \&Yıldı-Duban, 2007). Together 
with providing these opportunities from pre-school up to the end of higher education, science education;

- Helps students in obtaining the information and skills that will be beneficial for them throughout all their lives.

- Increases their life quality by ensuring that they learn to think critically, solve problems and make decisions.

- Increases their interest and sensitivity towards environmental problems and ensures that they take more responsibility in these subjects.

- Guides them towards participating in a universal society consisting of science literate individuals (Krajcik et al., 1999, p. 15-16).

Arousing curiosity among students, helping them understand the subjects that they will learn in a more detailed way in coming years, contributing to their gaining the skills that are necessary for them to learn these subjects, and guiding students towards making research by thinking within the framework of cause and effect relationships are among the properties that the training programs used in giving science education must possess (NRC, 2006; Victor and Kellough, 1997, p. 13). Taking these justifications into consideration, many countries developed science and technology teaching programs that will raise their citizens as science and technology literates. These programs developed suggest that students are effectively included in learning environments, are able to make changes and innovations and make new designs (Çepni, 2005). In these countries, inquiry-based learning is addressed as one of the most important components of program development studies. According to the National Science Education Standards published in the USA, there is a consensus that the objective of educators should be included in research-based education program, and the studies conducted have shown that research-based learning is more effective than traditional methods (Wilson, Taylor, Kowalski and Carlson, 2010; Colburn, 2006; Geier et al., 2008). In Turkey, secondary school Science and Technology Lesson Curriculum was changed in 2013 as "Science" Lesson Curriculum. One of the most striking innovations that are brought about by the change in this program is that the research and inquiry-based approach is taken as a basis (MNE, 2013). It is seen that the discussions and research on the improvement of science teaching and what good science teaching should be in the recent period gradually and increasingly focus on the importance of research and interrogation (Anderson, 2002).

Questioning in science education covers a process that includes providing students with the opportunities to create questions in achieving the information that they will structure within the learning process, structuring the research process, revealing the results and sharing the data obtained with other people (Lin Tuan, 2005). Inquiry-based learning showed up as an approach that helps students learn the learning that is effective in developing their higherorder thinking skillsand the constructivist theory as a basis (Minner, Levy and Century, 2009).In NSES determined by the National Research Council [NRC] in the USA in 1996, the research-based learning approach was expressed as a multi-dimensional process of researchbased learning, in which students ask questions and make observations, try to verify the information they have using their sources, and information is collected and analysed using the tools compared with the findings obtained from the experiments (NRC, 2000). In other words, this approach is an approach in which individuals use their creativity in the process of obtaining information by asking questions and doing research (Llewellyn, 2002; Burden and Byrd, 2003; Hammerman, 2006; Bass, Contantand Carin, 2008). Research-based learning is a process that consists of the activities, experiments, and explorations that students make in groups or by themselves, which ensure that the information is significant (Tatar and Kuru, 
2006). As can be understood, this approach includes a learning process in which students are active (Çalışkan, 2009) and present solution suggestions for the problems they encounter in their life and try to achieve the result by establishing the cause and effect relationship. The research-based learning approach may include case study activities, social activities, invention-based or project-based studies as it is also stated by Werner (2007). At the same time, in this approach, the student encounters the problem at the beginning of the learning process, then he/she presents solution suggestions, investigates these solution suggestions, implements them, and the process ends when the student finds the solution. In short, learning in this approach is a process that supports and develops the research skills, research knowledge, intellectual, spatial and personal skills and attitudes (Moore, Bramhall, Clarke and Craig, 2008).

Despite many advantages of inquiry-based learning, when the literature was examined, no sufficient study was encountered on the measurement or depicting of the attitudes and selfsufficiency of secondary school students regarding research and inquiry-based learning. It is seen that the studies carried out are more on the determination of understanding and research competence levels (Balım and Taşkoyan, 2007). It is interesting that attitude studies are generally performed as attitudes towards social sciences or science (Demirbaş and Yağbasan, 2005; Oruç and Ulusoy, 2008; Yücel, 2004). It is seen that self-sufficiency studies are generally aimed at examining the self-sufficiency of teachers and preservice teachers in regard to science teaching (Ramey and Shroyer, 1992; Akbaş and Çelikkaleli, 2006; Duran, Ballone-Duran, Haney and Beltyukova, 2009; İnaltekin and Akçay, 2012). In this framework, the objective of this study is to depict the attitudes and self-sufficiency of students regarding research and inquiry and reveal the relationship between them.

\section{Objective of the Study}

The objective of this study is to determine the attitude and self-sufficiency levels of the students in regard to research-inquiry.

(1) What are the attitudes and self-sufficiency levels of the students in regard to researchinquiry in general?

(2) Do the attitude and self-sufficiency levels of the students in regard to research-inquiry vary by gender?

(3) Do the attitude and self-sufficiency levels of the students in regard to research-inquiry vary by grade level?

(4) What kind of a relationship is there between the attitude and self-sufficiency levels of the students in regard to research-inquiry?

\section{Method}

\section{Research Model}

This study is a descriptive study. It was carried out in the screening model. In this context, it was attempted to determine the self-sufficiency perceptions and attitudes of the students towards research-inquiry-based learning. 


\section{Study Group}

234 secondary school students studying at $5^{\text {th }}-8^{\text {th }}$ grades in Amasya Taşova in the second semester of the 2015-2016 academic year make up the study group of this study. The distribution of the study group by gender is summarized in Table 1.

Table 1. The distribution of the study group by gender

\begin{tabular}{llll}
\hline \multicolumn{3}{c}{ Gender } \\
\hline Class & Female & Male & Total \\
$\mathbf{5}$ & 20 & 28 & 48 \\
$\mathbf{6}$ & 37 & 29 & 66 \\
$\mathbf{7}$ & 28 & 28 & 56 \\
$\mathbf{8}$ & 32 & 32 & 64 \\
Total & 117 & 117 & 234 \\
\hline
\end{tabular}

\section{Data Collection Tool}

The Self-Sufficiency Perception of Research-Inquiry Scale developed by Ebren Ozan, Korkmaz and Karamustafaoğlu (2016) was used for the self-sufficiency perceptions of the students in the context of this study. The validity and reliability study of the scale was performed on 233 secondary school students. The construct validity of the scale was tested using the exploratory and confirmatory factor analysis. Furthermore, the item factor correlation and item discrimination analyses were also performed. The two equal semicorrelations of the scale were determined as ,712; the Spearman-Brown reliability coefficient was determined as ,832; the Guttmann Split-Half value was determined as ,825; and the Cronbach's Alpha reliability coefficient was determined as,835. As a result of the analyses performed, the scale prepared in five-item Likert-type consists of 14 items and three factors. The construct validity results showed that the scale serves the purpose both in terms of each item and the whole. According to the t-test results, it is seen that the difference between the item scores of the upper and lower groups of $27 \%$ is significant, so the levels of discrimination are high. The results of the exploratory factor analysis showed that the structure of the scale is verified.

The Attitude Towards Research-Inquiry Scale developed by Ebren Ozan, Korkmaz and Karamustafaoğlu (2016) was used for students' attitudes within the scope of this study. The validity and reliability study of the scale was performed with 233 secondary school students. The construct validity of the scale was tested using the exploratory and confirmatory factor analysis. The item factor correlation and item discrimination analyses were also carried out. The two equal semi-correlations of the scale were determined as ,491; the Spearman-Brown reliability coefficient was determined as ,659; the Guttmann Split-Half value was determined as ,656; and the Cronbach's Alpha reliability coefficient was determined as ,756. As a result of the analyses performed, the scale prepared in five-item Likert-type consists of 13 items and three factors. The construct validity results showed that the scale serves the purpose both in terms of each item and the whole. According to the t-test results, it is seen that the difference between the item scores of the upper and lower groups of $27 \%$ is significant, so the levels of discrimination are high. The results of the exploratory factor analysis showed that the structure of the scale is verified. 


\section{Data Analysis}

The raw scores obtained from the factors were turned into standard scores, the lowest of which is 20 and the highest is 100; and percentage, arithmetic average, Anova, Schieffe and $t$ tests were used on the data in line with the sub-problems. The $p<0,05$ level was considered sufficient as the level of significance of the difference and relationships. Furthermore, the scores between 20 and 53 were qualified as "low"; between 54 and 69 as "intermediate", and higher than 70 were qualified as "high" as standard score equivalents.

\section{Findings}

\section{Attitudes and Self-Sufficiency of the Students in regard to Research-Inquiry}

The findings on the attitudes and self-sufficiency of the students in regard to researchinquiry are summarized in Table 2.

Table 2. Attitudes and self-sufficiency of the students

\begin{tabular}{|c|c|c|c|c|c|c|}
\hline & Variables & $\mathbf{X}$ & sd & $\begin{array}{l}\text { Low } \\
(\%)\end{array}$ & $\begin{array}{c}\text { Medium } \\
(\%)\end{array}$ & $\begin{array}{c}\text { High } \\
(\%)\end{array}$ \\
\hline \multirow{4}{*}{ 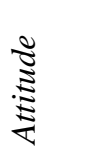 } & Inquisitiveness & 86,1 & 13,7 & 2,1 & 17 & 212 \\
\hline & Negative overview & 78,7 & 17,1 & 9 & 15,8 & 75,2 \\
\hline & Valuing & 77,5 & 15,1 & 6,4 & 18,8 & 74,8 \\
\hline & Total & 80,6 & 11,6 & 2,6 & 13,7 & 80,3 \\
\hline \multirow{4}{*}{ 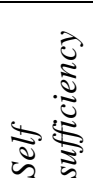 } & Avoidance & 75,7 & 18,6 & 13,2 & 21,8 & 65 \\
\hline & Resume Research & 83,8 & 13,2 & 1,7 & 11,1 & 87,2 \\
\hline & Personal evolution & 84,7 & 15,1 & 3,4 & 6,8 & 86,8 \\
\hline & Total & 80,1 & 13,1 & 2,6 & 19,7 & 77,8 \\
\hline
\end{tabular}

When the attitudes and self-sufficiency of the students in regard to research-inquiry in Table 2 are examined, it is seen that the average score for the attitudes is 80,6 and $80,3 \%$ of the students have a high level of attitudes. In Table 2, it is seen that the same applies to the factors in terms of the attitude. All of the items in the negative opinion factor are negative, and they were inversely coded before conducting the analyses. Thus, an increase in the score in this factor also indicates a positive attitude. Accordingly, it can be said that the attitude levels of the students towards research-inquiry are quite high.

In Table 2, it is seen that the average score for self-sufficiency is 80,1 and $77,8 \%$ of the students have a high level of self-sufficiency. In Table 2, it is seen that the same applies to the factors in terms of self-sufficiency. All of the items in the avoidance factor are negative, and they were inversely coded before conducting the analyses. Thus, the increase in scores in this factor shows positive self-sufficiency. However, the lowest averages also belong to the Avoidance factor. Accordingly, it can be said that the self-sufficiency levels of the students in regard to research-inquiry are quite high.

\section{Attitudes and Self-Sufficiency of the Students in regard to Research-Inquiry by Gender}

The findings on the attitudes and self-sufficiency of the students in regard to researchinquiry by gender are summarized in Table 3 . 
Table 3. Attitudes and self-sufficiency of the students in regard to research-inquiry by gender

\begin{tabular}{|c|c|c|c|c|c|c|c|c|}
\hline & \multicolumn{2}{|c|}{ Variables } & $\mathbf{N}$ & $\mathbf{X}$ & Ss & $\mathbf{t}$ & sd & $\mathbf{p}$ \\
\hline \multirow{7}{*}{ Attitude } & Inquisitiveness & $\begin{array}{l}\text { Female } \\
\text { Male }\end{array}$ & $\begin{array}{l}117 \\
117\end{array}$ & $\begin{array}{l}84,1 \\
87,9\end{array}$ & $\begin{array}{l}14,3 \\
12,8\end{array}$ & $-2,094$ & 232 & ,037 \\
\hline & \multirow{2}{*}{$\begin{array}{l}\text { Negative } \\
\text { overview }\end{array}$} & Female & 117 & 77,9 & 16,1 &,- 686 & 232 & ,494 \\
\hline & & Male & 117 & 79,5 & 18,1 & & & \\
\hline & \multirow{2}{*}{ Valuing } & Female & 117 & 77,8 & 15,4 & ,302 & 232 &, 763 \\
\hline & & Male & 117 & 77,2 & 14,8 & & & \\
\hline & \multirow{2}{*}{ Total } & Female & 117 & 79,8 & 11,3 & $-1,024$ & 232 & ,307 \\
\hline & & Male & 117 & 81,4 & 11,9 & & & \\
\hline \multirow{8}{*}{$\begin{array}{l}\text { Self } \\
\text { sufficiency }\end{array}$} & \multirow{2}{*}{ Avoidance } & Female & 117 & 73,8 & 19,5 & $-1,503$ & 232 & ,134 \\
\hline & & Male & 117 & 77,5 & 17,8 & & & \\
\hline & \multirow{2}{*}{$\begin{array}{l}\text { Resume } \\
\text { Research }\end{array}$} & Female & 117 & 83,1 & 13,2 &,- 795 & 232 & ,428 \\
\hline & & Male & 117 & 84,5 & 13,2 & & & \\
\hline & \multirow{2}{*}{$\begin{array}{l}\text { Personal } \\
\text { evolution }\end{array}$} & Female & 117 & 85,1 & 14,9 & ,316 & 232 & 752 \\
\hline & & Male & 117 & 84,4 & 15,3 & & & \\
\hline & \multirow{2}{*}{ Total } & Female & 117 & 79, & 13,4 & $-1,289$ & 232 & 199 \\
\hline & & Male & 117 & 81,2 & 12,9 & & & \\
\hline
\end{tabular}

When the attitudes of the students towards research-inquiry by the gender status are examined in Table 3, it is seen that the attitude levels do not vary both in terms of the total score $(\mathrm{t}(2-$ $232)=-1,024 ; p>0,05)$ and the two factors (Negative Opinion: $t(2-232)=-, 686$; Valuing: $t(2-$ $232)=, 302 ; \mathrm{p}>0,05)$. However, it is observed that the Curiosity: $t(2-232)=-2,094 ; \mathrm{p}<0,05$ factor varies in favour of male students in terms of gender. Accordingly, it can be said that gender is only effective in terms of the Curiosity factor of the students, and it has no effect for other factors and the total score. In Table 3, it is seen that the self-sufficiency levels of the students do not vary both in terms of the total score $(\mathrm{t}(2-232)=-1,289 ; \mathrm{p}>0,05)$ and the factors (Avoidance: $\mathrm{t}(2-232)=-1,503$; Maintaining the Research: $t(2-232)=-, 795$; Personal Development: $\mathrm{t}(2-232)=, 316 \mathrm{p}>0,05)$ upon examining their self-sufficiency in regard to research-inquiry by the gender status. Accordingly, it can be said that gender has no effect on the self-sufficiency levels of the students.

\section{Attitudes and Self-Sufficiency of the Students in regard to Research-Inquiry by Grade Level}

The findings on the attitudes and self-sufficiency in regard to research-inquiry by grade level are summarized in Table 4.

Table 4. The attitudes and self-sufficiency in regard to research-inquiry by grade level

\begin{tabular}{|c|c|c|c|c|c|c|c|c|c|}
\hline \multicolumn{10}{|c|}{ Attitudes } \\
\hline \multirow[b]{2}{*}{ Class } & \multirow[b]{2}{*}{$\mathbf{N}$} & \multicolumn{2}{|c|}{ Inquisitiveness } & \multicolumn{2}{|c|}{ Neg. Overview } & \multicolumn{2}{|c|}{ Valuing } & \multicolumn{2}{|c|}{ Total } \\
\hline & & $\bar{X}$ & Sd & $\overline{\mathrm{X}}$ & Sd & $\overline{\mathrm{X}}$ & Sd & $\overline{\mathrm{X}}$ & Sd \\
\hline 5. & 48 & 88,8 & 12,7 & 82,4 & 16,1 & 82,3 & 16,9 & 84,3 & 12,1 \\
\hline 6. & 66 & 85,2 & 13,9 & 76,2 & 20,7 & 77,2 & 15,1 & 79,3 & 12,9 \\
\hline 7. & 56 & 89,6 & 8,7 & 84,6 & 11,9 & 81,3 & 11,5 & 85,1 & 7,7 \\
\hline 8. & 64 & 81,6 & 16,4 & 73,4 & 15,9 & 70,9 & 14,3 & 75,1 & 10,1 \\
\hline Total & 234 & 86,1 & 13,7 & 78,7 & 17,1 & 77,5 & 15,1 & 80,6 & 11,6 \\
\hline
\end{tabular}

\begin{tabular}{lccccccccc}
\hline & \multicolumn{10}{c}{$\begin{array}{c}\text { Self-sufficiency } \\
\text { Avoidance }\end{array}$} & \multicolumn{1}{c}{ Res. Research } & Per. evolution & \multicolumn{2}{c}{ Total } \\
\hline \multicolumn{1}{r}{ Sinıflar } & $\mathbf{N}$ & $\overline{\mathrm{X}}$ & $\mathbf{S}$ & $\overline{\mathrm{X}}$ & $\mathbf{S}$ & $\overline{\mathrm{X}}$ & $\mathbf{S}$ & $\overline{\mathrm{X}}$ & $\mathbf{S}$ \\
\hline 5. & 48 & 79,3 & 18,1 & 86,9 & 13,4 & 85,9 & 16,9 & 83,5 & 13,9 \\
6. & 66 & 74,1 & 19,6 & 84,9 & 12,5 & 82,6 & 17,8 & 78,8 & 14,8 \\
7. & 56 & 82,7 & 16,2 & 86,4 & 12,5 & 89,8 & 10,2 & 85,3 & 11,1 \\
8. & 64 & 68,4 & 17,7 & 77,9 & 12,7 & 81,5 & 13,3 & 74,4 & 9,5 \\
\hline Total & 234 & 75,7 & 18,7 & 83,8 & 13,2 & 84,7 & 15,1 & 80,1 & 13,1 \\
\hline
\end{tabular}


Upon examining the attitude total scores of the studēnts by grade level in Table 4, it is seen that the highest average for the Curiosity factor is $=89,6$ in the 7 th grade, and the lowert average is $=81,6$ in the 8th grade. The highest avera for the Negative Opinion factor is $=84,6$ in the 7 th grade, and the Jowest average is $=73,4$ in the 8 th grade. The đighest average for the Valuing factor is $\quad=82,3$ in the 5th grade, and the lowwest average is $\quad=70,9$ in the 8th grade. The high $\bar{x}$ st average for the total attitude score is $=85,1$ in the 7 th grade, and the lowest average is $\quad=75,1$ in the 8 th grade.

Upon examining the self-sufficiency total scores of the students by grade level in Table 4, the highest average for the Avoidance factor is $\bar{X}=82,7$ in the 7 th grade, and the lowest average is $\bar{X}=68,4$ in the 8 th grade. For the factor of maintaining the research, the highest average is $\bar{X}=86,9$ in the 5 th grade and the lowest average is $\bar{X}=77,9$ in the 8 th grade. The highest average for the Personal Development factor is $\bar{X}=89,8$ in the 7 th grade, and the lowest average is $\bar{X}=81,5$ in the 8 th grade. The highest average for the total self-sufficiency score is $\bar{X}=85,3$ in the 7 th grade, and the lowest average is $\bar{X}=74,4$ in the 8 th grade.

The results of the variance analysis performed in order to determine whether this differentiation between the attitude and self-sufficiency scores in regard to research-inquiry is significant are summarized in table 5.

Table 5. Results of the variance analysis

\begin{tabular}{|c|c|c|c|c|c|c|c|c|}
\hline & & & $\begin{array}{l}\text { Sum of } \\
\text { Squares }\end{array}$ & df & $\begin{array}{l}\text { Mean } \\
\text { Square }\end{array}$ & $\mathbf{F}$ & Sig. & LSD \\
\hline \multirow{4}{*}{ 总 } & $\begin{array}{l}\text { Inquisitive } \\
\text { ness }\end{array}$ & $\begin{array}{l}\text { Between Groups } \\
\text { Within Groups } \\
\text { Total }\end{array}$ & $\begin{array}{l}2369,919 \\
41219,076 \\
43588,996 \\
\end{array}$ & $\begin{array}{l}3 \\
230 \\
233 \\
\end{array}$ & $\begin{array}{l}789,973 \\
179,213\end{array}$ & 4,408 &, 005 & Between 8 and 7 \\
\hline & $\begin{array}{l}\text { Negative } \\
\text { overview }\end{array}$ & $\begin{array}{l}\text { Between Groups } \\
\text { Within Groups } \\
\text { Total }\end{array}$ & $\begin{array}{l}4806,882 \\
63624,502 \\
68431,385 \\
\end{array}$ & $\begin{array}{l}3 \\
230 \\
233 \\
\end{array}$ & $\begin{array}{l}1602,294 \\
276,628\end{array}$ & 5,792 &, 001 & $\begin{array}{l}\text { Between } 8 \text { and } \\
5,7\end{array}$ \\
\hline & Valuing & $\begin{array}{l}\text { Between Groups } \\
\text { Within Groups } \\
\text { Total }\end{array}$ & $\begin{array}{l}4717,803 \\
48444,590 \\
53162,393 \\
\end{array}$ & $\begin{array}{l}3 \\
230 \\
233 \\
\end{array}$ & $\begin{array}{l}1572,601 \\
210,629\end{array}$ & 7,466 & ,000 & $\begin{array}{l}\text { Between } 8 \text { and } \\
5,7\end{array}$ \\
\hline & Total & $\begin{array}{l}\text { Between Groups } \\
\text { Within Groups } \\
\text { Total }\end{array}$ & $\begin{array}{l}3826,041 \\
27466,044 \\
31292,085\end{array}$ & $\begin{array}{l}3 \\
230 \\
233 \\
\end{array}$ & $\begin{array}{l}1275,347 \\
119,418\end{array}$ & $\begin{array}{l}10,68 \\
0\end{array}$ & ,000 & $\begin{array}{l}\text { Between } 8 \text { and } \\
5,7\end{array}$ \\
\hline \multirow{4}{*}{ 思 } & Avoidance & $\begin{array}{l}\text { Between Groups } \\
\text { Within Groups } \\
\text { Total }\end{array}$ & $\begin{array}{l}6936,020 \\
74439,176 \\
81375,196 \\
\end{array}$ & $\begin{array}{l}3 \\
230 \\
233 \\
\end{array}$ & $\begin{array}{l}2312,007 \\
323,649\end{array}$ & 7,144 & ,000 & $\begin{array}{l}\text { Between } 8 \text { and } \\
5,7\end{array}$ \\
\hline & $\begin{array}{l}\text { Resume } \\
\text { Research }\end{array}$ & $\begin{array}{l}\text { Between Groups } \\
\text { Within Groups } \\
\text { Total }\end{array}$ & $\begin{array}{l}3131,705 \\
37183,252 \\
40314,957 \\
\end{array}$ & $\begin{array}{l}3 \\
230 \\
233 \\
\end{array}$ & $\begin{array}{l}1043,902 \\
161,666\end{array}$ & 6,457 & ,000 & $\begin{array}{l}\text { Between } 8 \text { and } \\
\text { others }\end{array}$ \\
\hline & $\begin{array}{l}\text { Personal } \\
\text { evolution }\end{array}$ & $\begin{array}{l}\text { Between Groups } \\
\text { Within Groups } \\
\text { Total }\end{array}$ & $\begin{array}{l}2468,935 \\
50804,570 \\
53273,504 \\
\end{array}$ & $\begin{array}{l}3 \\
230 \\
233 \\
\end{array}$ & $\begin{array}{l}822,978 \\
220,889\end{array}$ & 3,726 & ,012 & $\begin{array}{l}\text { Between } 8 \text { and } \\
7\end{array}$ \\
\hline & Total & $\begin{array}{l}\text { Between Groups } \\
\text { Within Groups } \\
\text { Total }\end{array}$ & $\begin{array}{l}4266,418 \\
35924,312 \\
40190,729\end{array}$ & $\begin{array}{l}3 \\
230 \\
233\end{array}$ & $\begin{array}{l}1422,139 \\
156,193\end{array}$ & 9,105 & ,000 & $\begin{array}{l}\text { Between } 8 \text { and } \\
6,7\end{array}$ \\
\hline
\end{tabular}

Upon examining the students' attitudes towards research-inquiry by grade level in Table 5, it is seen that there is a significant difference among all attitude factors (Curiosity: $\mathrm{F}$ (3, 230) $=4,40$; Negative Opinion: $\mathrm{F}(3,230)=5,79$; Valuing: $\mathrm{F}(3,230)=7,46)$ and the total score $\mathrm{F}(3,230)=10,68$ in terms of grade levels, $\mathrm{p}<0.05$. Accordingly, there is a significant difference 
between the 7th and 8th grades in the Curiosity factor, and between the 8th grade and 5th and 7 th grades in terms of other factors and the total score.

Upon examining the students' self-sufficiency in regard to research-inquiry by grade level in Table 5, it is seen that there is a significant difference among all grade levels $F(3,230)=9,10$ in terms of all of the self-sufficiency factors (Avoidance: F $(3,230)=7,14$; Maintaining the Research:F(3, 230) $=6,45$; Personal Development: $F(3,230)=3,72)$ and the total score, $\mathrm{p}<0.05$.Accordingly, there is a significant difference between the 8th and 5th and 7th grades in the Avoidance factor; between the 8th grade and other grades in Maintaining the Research factor; between the 8th grade and 7th grade in the Personal Development factor; and between the 8th grade and 6th and 7th grades in terms of the total score.

\section{Relationship between the Attitude and Self-Sufficiency Levels of the Students in regard to Research-Inquiry}

The findings on the relationship between the attitudes and self-sufficiency of the students in regard to research and inquiry are summarized in Table 6.

Table 6. Relationship between the attitudes and self-sufficiency of the students

\begin{tabular}{lcccc}
\hline & Avoidance & $\begin{array}{c}\text { Resume } \\
\text { Research }\end{array}$ & $\begin{array}{c}\text { Personal } \\
\text { evolution }\end{array}$ & $\begin{array}{c}\text { Self- } \\
\text { sufficiency }\end{array}$ \\
\hline Inquisitiveness &, 555 &, 450 &, 460 &, 607 \\
Negative overview &, 758 &, 497 &, 538 &, 816 \\
Valuing &, 603 &, 453 &, 486 &, 675 \\
Attitude &, 874 &, 628 &, 668 &, 955 \\
\hline $\mathrm{P}<0,01, \mathrm{~N}=234$ & & & &
\end{tabular}

Upon examining Table 6, it is seen that there is a significant difference between the attitudes and self-sufficiency of the students in regard to research and inquiry at a level of 0,955, $\mathrm{r}=0,955, \mathrm{p}<0.05$. This shows that there is a positive and significant relationship at a high level. It is also seen that there is a significant and positive relationship between the attitude factors and self-sufficiency factors. This can be interpreted as the self-sufficiency levels of the students will increase as their attitude levels towards research-inquiry increase.

\section{Discussion and Conclusion}

1. As a result of the study carried out, the attitudes and self-sufficiency of the students in regard to research and inquiry are quite high. Similarly, it is seen that there is a high relationship between the inquiry-based learning and the attitude levels of the students towards science in the literature (Akpullukçu, 2011; Alouf and Bentley, 2003; Lord and Orkwiszewski, 2006; Sakar, 2010; Tatar, 2006). Furthermore, it was determined in the study of Laipply (2004) examining the effect of inquiry-based learning practices on the attitude and self-sufficiency levels of students in regard to science, it was determined that the attitude and self-sufficiency levels of the students are high.

2. According to the result of the study carried out, gender does not have any effect on the attitude and self-sufficiency levels of the students in regard to research and inquiry. Similarly, the self-sufficiency levels of teachers concerning inquiry in the literature do not vary by gender (Çelikkaleli, 2006; Gerçek et al., 2006; Torkzadeh \& Koufteros, 1994). Furthermore, in Evren's (2012) master's thesis investigating whether the attitude levels of the students towards inquiry vary by gender and grade level, it was concluded that the attitude levels of the students do not vary by gender. 
3. According to the result of the study conducted, there is a significance difference between the attitudes and self-sufficiency of the students in regard to research and inquiry by grade level. There is a significant difference between the $8^{\text {th }}$ grade and $5^{\text {th }}$ and $7^{\text {th }}$ grades in terms of attitude levels in favour of the $8^{\text {th }}$ grades, and between the $8^{\text {th }}$ grade and $6^{\text {th }}$ and $7^{\text {th }}$ grades in terms of self-sufficiency levels in favour of the $8^{\text {th }}$ grades. However, in the literature, it was determined in Evren's (2012) master's thesis investigating whether the attitude levels of the students towards inquiry vary by gender and grade level, it was determined that the attitude levels of $8^{\text {th }}$-grade students are higher than those of $6^{\text {th }}$ and $7^{\text {th }}$ grade students. This may result from other factors affecting the research performance. The interests, attitudes, worries, and wishes (Büyüköztürk, 1997; Saracaloğlu et al., 2005) of the individuals and research self-sufficiency (Bieschke, Bishop and Garcia, 1993; İpek et al., 2010) are among the factors affecting the research performance.

4. According to the result of the study carried out, there is a positive and high-level relationship between the attitudes and self-sufficiency levels of the students in regard to research and inquiry. It is seen in the literature that there is a relationship between the attitude and self-sufficiency levels in regard to research and inquiry. Research self-sufficiency affects the research effectiveness (Bard, Bieschke, Herbert and Eberz, 2000; Hollingsworth and Fassinger, 2002; Phillips, 1992; Phillips and Russell, 1994) and the attitudes and approaches towards the research (Bard et al., 2000).

\section{Reference}

Akbaş, A., \& Çelikkaleli, Ö. (2006). Class teachers' science teaching self-efficacy beliefs of sex, examination according to the type of education and universities. Mersin University Faculty of Education Journal, 2 (1).

Akpullukçu, S. (2011). Academic success of students learning environment based on research in science and technology courses, retention level and its impact on attitude. (Unpublished master's thesis). Dokuz Eylul University, Izmir. YÖK National Thesis were obtained from the central database. (Thesis No. 286479 ).

Alouf, L. J. ve Bentley, M. L. (2003). Assessing the impact of inquiry-based science teaching in professional development activities, PK-12. Annual Meeting of the Association of Teacher Educators. Jacksonville, Florida.

Anderson, R. D.(2002).Reforming science teaching: What research says about inquiry. Journal of science teacher education, 13(1), 1-12.

Arslan, C. (2005). "Education Reform" .http: /mimas.politics.ankara.edu.tr/aksoy reform / erlist05b.htm (Accessed on: 13 May 2007).

Bard, C. C., Bieschke, K. J., Herbert, J. T. and Eberz, A. B. (2000). Predicting Research Interest Among Rehabilitation Counselling Students and Faculty. Rehabilitation Counseling Bulletin, 44, 1, 48-55.

Bass, J. E., Contant, T. L., \& Carin, A. A. (2008). Methods for teaching science as inquiry. Pearson Merrill.

Bieschke, K. J., Bishop, R. M., and Garcia, V. L. (1993). A Factor Analysis of the Research Self-Efficacy Scale. Paper Presented at the Annual Meeting of the American Psychological Association, Toronto, Canada, 20-24.

Burden, R. P., \& Byrd, D. M. (2003). Methods for effective teaching. Boston: Allynand Bacon.

Büyüköztürk, S. (1997). Development of Anxiety Inventory-Oriented Research. Education Management, 4, 453-464.

Bozdoğan, A. E. (2016). Development of Teaching Packs of Exhibitions in Science Centres into Elementary School Science Curriculum for Grades 5-8: Konya Science Centres 
Sample, Participatory Educational Research (PER), 4(1): 26-31

Colburn, A. (2006). What teacher educators need to know about inquiry-based instruction. $w^{\prime} w w$. csulb. edu/ acolbum/AETS. htm.

Çalışkan, H. (2009). Social studies the effects of critical thinking skills of research-based learning approach in teaching. Kastamonu Education Journal, 17 (1), 57-70.

Çepni, S. (2005). Science, Science, Reflections on Technology and Education Program. Application of the Theory of Science and Technology Öğretimi.3. Printing. Editor: Salih Çepni. Ankara: Pegem-Publishing.

Demirbaş, M. ve Yağbasan, R. (2005). Based on Social Learning Theory of Teaching Activities, Student Persistence of Investigation of the Effects of Scientific Attitude. Journal of the Uluda ğ University Faculty of Education. 18 (2), 363-382.

Duran, E., Ballone-Duran, L., Haney, J., \&Beltyukova, S. (2009). The impact of a Professional development program integrating informal science education on early childhood teachers'self-efficacy and beliefs about inquiry-based science teaching. Journal of Elementary Science Education, 21(4), 53-70.

Ebren Ozan, C., Korkmaz, Ö., Karamustafaoğlu, S. (2016 Secondary school students' self efficiency perception scale for research inquiry. Turkish Journal of Social Researches, 20(3):679-696

Evren, B. (2012). Impact of Science and Technology of Inquiry Learning Approach to Teaching Students Owned Level Critical Thinking and Attitudes toward Science and Technology Course. Unpublished Master's Thesis. Adnan Menderes University, Institute of Science and Aydin.

Geier, R., Blumenfeld, P. C., Marx, R. W., Krajcik, J. S., Fishman, B., Soloway, E., \&Clay-Chambers, J. (2008). Standardized test out comes for students engaged in inquiry-based science curricula in the context of urban reform. Journal of Research in Science Teaching, 45(8), 922-939.

Gerçek, C., Yilmaz, M., Köseoğlu, P. \& Soran, H. (2006). Self-Efficacy Beliefs in Teaching of Biology Education Teachers. Ankara University Faculty of Educational Sciences Journal, 39 (1), 57-73.

Hammerman, E. (2006). Eight essentials of inquiry-based science, $K$-8. Corwin Press.

Hollingsworth, M. A. ve Fassinger, R. E. (2002). The Role of Faculty Mentors in the Research Training of Counselling Psychology Doctoral Students. Journal of Counselling Psychology, 49, 3, 324-330.

İnaltekin, T., Özyurt, B. B., \& Akçay, H. (2012). Primary 6th, 7th and 8th Grade Textbook Evaluation of Science and Technology activities. Trakya University Faculty of Education Journal, 2 (2).

İpek, C., Tekbıyık, A. and Ursavaş Ö. F. (2010). Graduate Research Self-Efficacy Beliefs and Attitudes of student computers. Gaziantep University Journal of Social Sciences, 9, 1, 127-145.

Krajcik, J. S., Czerniak, C., \& Berger, C. (1999). Teaching children science: A project-based approach. McGraw-Hill College.

Laipply, R. S. 2004. A Case Study Of Self-Efficacy And Attitudes Toward Science Ġn An Ǵnquiry-Based Biology Laboratory. Akron University, PhD Thesis, Ohio.

Lord, T. ve Orkwiszewski, T. (2006). Moving from didactic to inquiry-based instruction in a science laboratory. The American Biology Teacher, 68, 342-345.

Llewellyn, D. (2002). InquiryWithin: Implementing Inquiry- Based Science Standarts.USA: Corwinn Pres, Inc. A Sage Publications Company.

Ministry of Education (2013). Science Teaching (3, 4, 5, 6, 7 and 8 classes) Curriculum, Ankara. 
Minner, D. D., Levy, A. J., \& Century, J. (2010). Inquiry-based science instruction-what is it anddoes it matter? Results from a research synthesis years 1984 to 2002. Journal of research in science teaching, 47(4), 474-496.

Moore, I., Bramhall, M., Clarke, J., \&Craig, C. (2008). OK Bloggs, Just Watch theBlackboardWhile I Run Through 1t: What Has Elearning Got to Do with EBL?. In 3rd Learning Through Inquiry Alliance (LTEA) Conference: 'Inquiry $n$ A Networked World', United Kingdom.

NRC (NationalResearchCouncil). (2006). Taking Science to School: Learning and Teaching Science in Grades K-8.Editors: R. A. Duschl, H. A. Schweingruber and A.W. Shouse. Washington, D.C.: National Academies Press.

Oruç,S. and Ulusoy, K. (2008). Thesis work done in social studies teaching field. Selcuk University, Ahmed Keleşoğlu Education Faculty Journal, 26, 121-132.

Phillips, J. C. (1992). Research Self-Efficacy And The Research Training Environment In Counseling Psychology. Doctoral Thesis. The Ohio State University, Department of Psychology, USA.

Phillips, J. C. ve Russell, R. K. (1994). Research Self-Efficacy, The Research Training Environment And Research Productivity Among Graduate Students In Counseling Psychology. Counseling Psychologis, 22, 628-641.

Ramey-Gassert, L., \&Shroyer, M. G. (1992). Enhancing science teaching self-efficacy in preservice elementary teachers. Journal of Elementary Science Education, 4(1), 26-34.

Sakar O. (2010). Effect on academic achievement and attitude of the students of the researchbased teaching chemistry. (Unpublished master's thesis). Selçuk University, Konya. YÖK National Thesis were obtained from the central database. (Thesis No. 264 321).

Saracaloğlu, A. S., Varol, S. R. ve Evin Ercan, İ. (2005). Concerns Students Graduate Research Training, Research and Competencies of Relationship Between Attitudes Survey Statistics. The School of Education Journal, 17, 187-199.

Taşkoyan, S. N. (2008). Inquiry of Science and Technology Education for Students in Inquiry Learning Strategies Learning Skills, Academic Achievement and Attitude Influence on. Unpublished Master's Thesis. Dokuz Eylul University, Institute of Educational Sciences: Izmir.

Tatar, N. (2006). Primary education in science process skills based learning approach to scientific research, the effect of academic achievement and attitude. (Unpublished doctoral dissertation). Gazi University, Ankara. YÖK National Thesis were obtained from the central database. (Thesis No. 187 259).

Tatar, N., \& Kuru, M. (2006). The impact on academic achievement of research-based learning approach in science education. Hacettepe University Faculty of Education Journal, 31 (31).

Torzadeh, G., Koufteros, X. (1994). Factorial validity of a computer self -efficacy scale and the impact of computer training, Education and Psychological Measument, Vol. 54, 3, 813- 821.

Ün Açıkgöz, K. (2011). Active Learning (12th edition). Izmir: IT education.

Victor, E. \&Kellough, R.D. (1997). Science For The Elementary and Middle School.Eight Edition. USA:Prentice-Hall, Inc., New Jersey.

Werner, R. J. (2007). Inquiry-Based Learning at Minnesota'sUniversity of St. Thomas. International Journal of Learning, 14(1).

Wilson, C. D., Taylor, J. A., Kowalski, S. M., \&Carlson, J. (2010). There lative effects andequity of inquiry-based and common place science teaching on students' knowledge, reasoning, and argumentation. Journal of research in science teaching, 47(3), 276-301. 
Yaşar, S., \& Duban, N. Y. (2007). An Exemplary Approach within the Scope of Inquirybased Learning in Science and Technology Course forthe 5th Grade Students in Primary Education in Turkey. International Journal of Learning, 14(3).

Yücel, A. S. (2004). Students in Chemistry Courses at Secondary Level Examination of Attitudes toward Homework given. Gazi University, Journal of Gazi Education Faculty. 24 (1), 147-159. 